\title{
Central Nervous System Plus Autonomic Nervous System Disorders Responsible for Gastrointestinal and Pancreatobiliary Diseases
}

\author{
Fuad Lechin · Bertha van der Dijs
}

Received: 4 March 2008/ Accepted: 3 June 2008 / Published online: 16 July 2008

(C) The Author(s) 2008

\begin{abstract}
Clinical digestive disorders depend on the nonadequate coupling of functioning of the gastrointestinal tract with that of its affluent systems, namely, the pancreatic exocrine and the hepato-biliary secretions. The secretion of gastrointestinal hormones is monitored by the peripheral autonomic nervous system. However, the latter is regulated by the central nervous system (CNS) circuitry localized at the medullary pontine segment of the CNS. In turn, both parasympathetic and adrenergic medullary circuitries are regulated by the pontine A5 noradrenergic (NA) and the dorsal raphe serotonergic nuclei, respectively. DR-5HT is positively correlated with the C1-Ad medullary nuclei (responsible for adrenal gland secretion), whereas the MR-5HT nucleus is positively correlated with the A5-NA pontomedullary nucleus. The latter is responsible for neural sympathetic activity (sympathetic nerves). Both types of sympathetic activities maintain an alternation with the peripheral parasympathetic branch, which is positively correlated with the enterochromaffin cells that secrete serotonin. Serotonin displays hormonal antagonism to the circulating catecholamines.
\end{abstract}

Keywords Autonomic nervous system .

Pancreato-biliary diseases - Neural-sympathetic disorders . Adrenal-sympathetic disorders · Gastrointestinal motility · Biliary motility

F. Lechin $(\varangle) \cdot$ B. van der Dijs

Departments of Neurophysiology, Neurochemistry, Neuropharmacology and Neuroimmunology, Instituto de Medicina Experimental, Faculty of Medicine, Universidad Central de Venezuela, Apartado 80.983, Caracas 1080, Venezuela

e-mail: flechin@telcel.net.ve

\section{Introduction}

The coupling of both secretory and motility activities of the different sections of the gastrointestinal and the biliary and pancreatic segments of the digestive tract favors the parallelism of the digestive, absorptive, and motility activities that guarantee the maximal utilization of the ingested nutrients. However, it should also guarantee the descending gradient of pressure, which allows the normal progression of the nutrients with a minimum of waste. This physiological target is accomplished because the different segments of the digestive tract (esophagus, stomach, duodenum, small bowel, colon, and rectum) are separated by adequate sphynctereal rings that should be chronologically opened and closed in order to allow the progression and impede refluxes of the ingested food. In addition to the above, the hepato-biliary and pancreatic flowings should pass over the biliary and pancreatic ductular channels before reaching the choleducus, at which end the sphincter of Oddi acts as a semaphore that requires several neuroautonomic and hormonal requirements before giving the green light to allow the flow of the biliary and pancreatic juice to the duodenum. Accordingly, these complex motility and secretory mechanisms guarantee the sequential functioning of the different branches of the digestive tract addressed to allow an adequate performance of the digestive and absorptive processes; however, taking into account the many physiological factors (hormonal as well as ANS) that interact at these levels, it would be easy to understand the lability of the above functioning, which is submitted to many types of stressor agents able to interfere with the physiology of the ANS, which is responsible for it. Special mention should be made of the iatrogenic pharmacological manipulations that should be included among the most frequent causes of gastrointestinal diseases [1-3]. 
Neuroautonomic and Hormonal Factors Involved in the Gastrointestinal and Pancreato-Biliary Physiology

Esophageal motility and emptying depends on the esophageal-gastric sphincter, which contracts and relaxes according to the intra-gastric $\mathrm{pH}$. Contractile response is registered when the $\mathrm{pH}$ is low and tends to relax when it rises. It is maximally open when gastric acid disappears. The fact that the enhancement of gastric acidity tends to close the pyloric sphincter also indicates that both the esophageal and the duodenal mucosa should be protected from the gastric acid secretion. Conversely, the duodenal mucosa is physiologically adapted to the alkalinity of the pancreato-biliary secretion, which is able to neutralize the acidity of the gastric shove in such a way that an adequate intermission of the pyloric sphincter aperture grants the necessary accomplishment of the neutralization of the gastric acid flow. Impairment of this physiological mechanism favors the ulceration of the duodenal mucosa. Conversely, the disappearance of the gastric acid content facilitates the duodenal-gastric reflux of bilis, bicarbonate, and pancreatic enzymes, which are able to damage both gastric and esophageal mucosa. This phenomenon is frequently registered in patients taking omeprazole and any other similar drugs [4].

Hormonal factors also play both physiological and pathophysiological roles. Gastrin enhances both gastric acid and pancreato-biliary flowing. Conversely, duodenal hormones such as secretin, pancreozymin, and cholecystokinin (CCK) enhance pancreato-biliary secretions as well as gallbladder and biliary motility. However, these hormones are coupled with the ANS mechanisms into a complex physiological interaction in such a way that any ANS disorder triggers the physiological unbalance responsible for different gastrointestinal and pancreatobiliary dysfunctions $[5,6]$. In addition, it has been demonstrated that CCK plays primordial physiological and pathophysiological roles in the motility of the colon [7, 8]; in addition, this gastrointestinal hormone crosses the blood brain barrier, at which level it interacts with CCK receptors located at the dorsal raphe serotonergic nucleus DR-5HT and provokes satiety $[9,10]$. Underlying this physiological phenomenon is the reduction of both gastrointestinal motility and secretions and the inhibition of the distal colon motility. Thus, physicians should be aware that the pharmacological manipulation of drugs addressed to treat gastrointestinal diseases provokes both peripheral and CNS effects.

According to the above, we will try to summarize the most relevant pathophysiological and neuropharmacological mechanisms underlying gastrointestinal and pancreatobiliary disorders as well as the hormonal plus the ANS and
CNS mechanisms associated with them. In addition, we will try to introduce readers into the most relevant factors that interact with both the CNS and the ANS areas.

\section{The Peripheral Autonomic Nervous System (ANS)}

Whereas the sympathetic activity depends on two peripheral branches, neural and adrenal [11], parasympathetic activity is displayed by nerves that release acetylcholine (ACh) [3]. However, serotonin (5HT) released from the enterochromaffin cells during parasympathetic excitation is able to antagonize peripheral sympathetic activity [12]. In addition, 5HT-neurons located at the myenteric plexa send excitatory axons to the muscular longitudinal external intestinal layer [13, 14]. Furthermore, 5HT released from the enterochromaffin cells excites pancreatic exocrine [1519] and inhibits pancreatic endocrine secretion [20-22], respectively.

Sympathetic nerves arise from the lumbar sympathetic acetylcholinergic (ACh) neurons, whereas adrenal glands receive excitatory axons from the thoracic sympathetic ACh-neurons [23]. The former sympathetic branch receives excitatory axons from the A5-NA nucleus (located at the pontomedullary area), whereas the adrenal sympathetic branch receives excitatory axons from the C1-Ad medullary nuclei $[24,25]$. Thus, taking into account that sympathetic nerves release $80 \%$ of noradrenaline (NA), whereas adrenal glands secrete $80 \%$ of $\mathrm{Ad}$, the NA/Ad plasma ratio reflects the proportional participation of both sympathetic branches [26]. In addition, considering that the A5-NA and the C1-Ad nuclei interchange inhibitory axons [27], it should be easy to understand that the assessment of the circulating catecholamines should afford adequate information about the proportional participation of these two sympathetic branches [28, 29]. Finally, it should be known that, whereas the A5-NA neurons send inhibitory axons to the medullary vagal $(\mathrm{ACh})$ nuclei $[30,31]$, the C1-Ad nuclei send and also receive axons from the medullary vagal complex [27, 32].

The above-summarized crosstalk explains the fast alternancy frequently registered between the adrenal sympathetic versus parasympathetic activity as well as the slow alternation that might occur between the other binomial (neural sympathetic vs. parasympathetic) [29]. In addition, it should be remembered that both NA and $\mathrm{Ad}$ axons inhibit Ad and NA postsynaptic neurons, respectively, which are crowded with alpha-2 inhibitory receptors [33]. This pharmacological data explains why alpha-2 agonists and/or antagonists are able to interfere with both types of sympathetic predominance.

According to the above-summarized information, it is understandable that an adequate assessment of the ANS 
disorders should include the determination of all circulating neurotransmitters. With respect to this, we report that our institute has assessed those parameters in some 30,000 normal and diseased subjects, not only during supineresting (fasting) conditions, but also after many types of challenges (orthostasis, exercise, oral glucose, and many CNS-acting drugs) [34-47].

Although acetylcholine is not detectable in the peripheral blood, the assessment of both plasma and platelet serotonin (f-5HT and p-5HT) affords adequate information about this parasympathetic parameter. However, considering that increased platelet aggregation triggers the enhancement of f-5HT registered during stress periods, which depends on the raised levels of plasma Ad [42, 44, 48], the assessment of f-5HT carried out during non-stress periods reflects parasympathetic activity, because plasma ACh competes with serotonin for platelet uptake. In other words, f-5HT is positively correlated with plasma ACh levels [49-53]. Cardiovascular parameters parallel ANS disorders. For instance, heart rate is positively correlated with adrenal sympathetic activity, whereas diastolic blood pressure depends on neural sympathetic activity. With respect to this, we have demonstrated that an accurate assessment of these cardiovascular parameters at the 1-min orthostasis challenge affords information that allows knowing which of the two peripheral sympathetic branches is predominant [28, 36-38].

\section{Pathophysiological Data Related to Some Gastrointestinal Diseases}

\section{Gastritis}

Type A (antral) gastritis is frequently underlain by a TH-2 immunological profile (adrenal sympathetic overactivity) and is frequently associated with duodenal ulceration [54, 55]. Parasympathetic rebounds, always registered during nocturnal (sleep) periods, are responsible for the appearance of duodenal ulcers [1, 2, 56-59]. In our long experience with this issue, the attenuation of both the diurnal adrenal sympathetic and the nocturnal parasympathetic rebounds is enough to revert both the uncoping stress situation and the gastroduodenal damage. This target is reached through neuropharmacological therapy, which includes small doses of NA uptake inhibitors (at diurnal period) plus small doses of NA and 5HT uptake inhibitors before bed. With respect to the above, it should be remembered that the iatrogenic effect triggered by drugs that interfere with the $\mathrm{K}^{+}$and $\mathrm{NA}^{+}$versus $\mathrm{H}^{+}$pumps interchange destroys the mucosal barrier, provokes the disappearance of antral acidity, and facilitates duodenogastric reflux because of the permanent antral alkalinity
[59-61]. In addition, evidence has demonstrated that helicobacter pylori favors the TH-1 immunity profile, which protects against malignancy [62]. Furthermore, the gastric to esophageal reflux of bilis is responsible for esophagitis, which is also provoked by this iatrogenic factor. The esophagic sphincter remains open because of the alkalinization of the gastric content. This phenomenon is enhanced during the recumbent nocturnal periods when parasympathetic predominance increases alkaline-pancreato-biliary secretions. This iatrogenic phenomenon is more evident in cholecystectomized patients, because bilis is not stored in the gallbladder. Accordingly, we believe that an adequate neuropharmacological therapy is the only therapeutical strategy able to revert the above-mentioned iatrogenic deleterious pathophysiologic disorders [4, 33, 63-70].

Additional information has demonstrated that type $B$ gastritis is present in subjects affected by neural sympathetic predominance. These subjects present with a TH-1 immunological profile because they have low levels of circulating Ad. This catecholamine favors the appearance of malignant diseases because it interferes with the destruction of malignant cells by the natural killer (NK) cells. This issue was demonstrated and published by our research group in 1987 [24, 42, 71-79] and has been confirmed by other researchers [80]. Thus, any neuropharmacological therapy of patients affected by malignant diseases should include the reversion of the adrenal over the neural sympathetic predominance.

\section{Reflux Esophagitis}

This disorder is also underlain by diurnal adrenal sympathetic overactivity that is reversed by parasympathetic overactivity in the nocturnal periods. Hence, these patients should also be treated with neuropharmacological manipulation addressed to enhance diurnal neural sympathetic activity. With respect to the above, we should emphasize that the nocturnal parasympathetic rebound, always registered in these patients, allows the duodenal and gastric reflux to the esophagus because the neural sympathetic hypoactivity allows the permanent aperture of both the pyloric and cardial sphincters [81, 82]. This phenomenon obliges attempting the normalization of the sleep disorder that is always present in these patients. With respect to this, it has been exhaustively demonstrated that in normal subjects, adrenal sympathetic activity reaches near zero values 10-15 min after the supine-resting state [34, 64, 69, 70]. On the contrary, neural sympathetic activity (which closes the sphincter) fades gradually and reaches minimal values (never zero values) at the REM sleep periods (90 min after the sleep initiation) [34, 83]. Thus, the absence of the slow wave sleep (SWS) period always registered in stressed 
mammals [84] interferes with the sphincter closure and favors biliary-gastro-esophageal reflux. Accordingly, normalization of the sleep disorder should constitute an imperative therapeutic step, addressed to reach the above target. However, a scientific neuropharmacological manipulation, but not the administration of benzodiazepines, should be prescribed. With respect to this, we would refer readers to our last books [24, 25].

With respect to the above, we will summarize the CNS disorders responsible for the raised levels of adrenaline and cortisol registered in stressed patients. The raised cortisol plasma levels depend on the hypersecretion of corticotropin-releasing hormone $(\mathrm{CRH})$ by the hypothalamus. Dorsal raphe axons release serotonin at this level, which excites CRH neurons. In addition, DR-5HT axons excite also the C1-Ad nuclei, which enhance adrenal sympathetic activity [85]. Over-excitation of the C1-Ad nuclei (adrenal sympathetic activity) inhibits the A5-NA nucleus, which is responsible for the peripheral neural sympathetic activity. Thus, any neuropharmacological treatment of the stress situation should include the reversion of the C1-Ad over
A5-NA predominance. This target is reached with the administration of a small dose of drugs that inhibits the uptake of NA at diurnal periods and a small dose of drugs that inhibits both the NA and the 5HT uptake at nocturnal periods. This manipulation also improves the sleep cycle. The above neuropharmacological strategy fits well with the successful neuropharmacological treatment of duodenal ulcer with doxepin (inhibits both NA and 5HT uptake) reported many years ago [61] and since then further confirmed.

\section{Irritable Bowel Syndrome and Biliary Dyskinesia}

Neural sympathetic activity contracts pyloric, ileocecal, and Oddi sphincters and, in addition, contracts the sigmoidal rectal junction. At the same time, this branch of the peripheral autonomic nervous system (ANS) antagonizes the dilator effect triggered by CCK at these levels; hence, overactivity of this ANS branch interferes with the CCK released during the postprandial periods and interrupts the biliary, ileal, and sigmoidal flow to the post-junctional

Table 1 Neuroautonomic plus immunological profiles underlying gastrointestinal and pancreato-biliary diseases

\begin{tabular}{|c|c|c|c|c|}
\hline $\begin{array}{l}\text { Central pathways activated } \\
\text { Neurochemical profile } \\
\text { Immunological profile }\end{array}$ & $\begin{array}{l}\text { Adrenal }>\text { neural } \\
\text { Sympathetic predominance } \\
\text { C1(Ad) } \\
\text { Uncoping stress } \\
\text { TH-2 }\end{array}$ & & $\begin{array}{l}\text { Neural > adrenal } \\
\text { Sympathetic predominance } \\
\text { A5(NA) } \\
\text { Endogenous depression } \\
\text { TH-1 }\end{array}$ & \\
\hline ANS profile & Ad. S. & P. S. & N. S. & P. S. \\
\hline \multicolumn{5}{|l|}{ Gastrointestinal diseases } \\
\hline Reflux esophagitis & $\mathrm{x}$ & $\mathrm{x}$ & & \\
\hline Type A gastritis & $\mathrm{x}$ & $\mathrm{x}$ & & \\
\hline Type B gastritis & & & $\mathrm{x}$ & \\
\hline Gastric ulcer & $\mathrm{x}$ & $\mathrm{x}$ & & \\
\hline Duodenal ulcer & & & $\mathrm{x}$ & $\mathrm{x}$ \\
\hline Acute pancreatitis & $\mathrm{x}$ & $\mathrm{x}$ & & \\
\hline Biliary dyskinesia & & & $\mathrm{x}$ & $\mathrm{x}$ \\
\hline Spastic colon & & & $\mathrm{x}$ & \\
\hline Nervous diarrhea & $\mathrm{x}$ & $\mathrm{x}$ & & \\
\hline Ulcerative colitis & $\mathrm{x}$ & $\mathrm{x}$ & & \\
\hline Granulomatous colitis (Crohn's) & & & $\mathrm{x}$ & \\
\hline Carcinoid syndrome & $\mathrm{x}$ & $\mathrm{x}$ & & \\
\hline Pancreatic cyst fibrosis & $\mathrm{x}$ & $\mathrm{x}$ & & \\
\hline Malignant diseases & $\mathrm{x}$ & & & \\
\hline
\end{tabular}

Uncoping stress: Adrenal gland secretion of catecholamines (Ad 80\%, NA 10\%, and DA 10\%) predominates over sympathetic nerve release of catecholamines (NA 80-90\% and DA 10-20\%). Overactivity of the CNS C1(Ad) nuclei triggers excitation of the vagal (medullary) nuclei, which is responsible for the peripheral parasympathetic nerve activity. Thus, alternance of these two ANS peripheral branches is frequently registered in patients affected by uncoping stress syndrome (adrenal stage = Ad. S.; parasympathetic stage = P. S.). Predominance of both Ad and cortisol are responsible for the TH-2 immunological predominance

Endogenous depression: Absolute predominance of neural over adrenal sympathetic activity underlies this CNS and ANS profile (neural sympathetic stage = N. S.). At the CNS level, the A5(NA) nucleus exerts maximal inhibition of both the C1(Ad) and vagal (medullary) nuclei. This CNS disorder is responsible for the disappearance of both adrenal and parasympathetic peripheral activities. In addition, the inhibition of the adrenocortical glands is responsible for the disinhibition of the thymus, which redounds in the TH- 1 immunological profile 
segments $[5,7,8,86-90]$. The above phenomena are registered during the spastic colon period of the IBS. The fact that clonidine, a CNS-acting alpha- 2 agonist that suppresses both neural and adrenal sympathetic overactivities by acting at the A5-NA and/or C1-Ad CNS nuclei, supports our postulation [87-102]. Both CNS nuclei are crowded by alpha-2 inhibitory receptors; hence, the drug would act at the hyperactive, but not at the hypoactive nucleus. Furthermore, considering that both CNS nuclei interchange inhibitory axons, alpha-2 agonists and/or antagonists are able to revert the physiological predominance of any of both systems. In addition, it is important to know that whereas the C1-Ad nuclei are positively correlated with the dorsal raphe (DR) serotonergic nucleus, the A5-NA nucleus parallels the activity of the median raphe (MR) serotonergic nucleus (MR-5HT) [103, 104]. Finally, it should be known that both serotonergic nuclei interchange inhibitory axons. Summarizing the above, it has been established that whereas the DR-5HT + C1-Ad hyperactivity is responsible for the uncoping stress syndrome, the MR-5HT + A5-NA binomial predominates in patients affected by endogenous depression as well as in patients affected by neural sympathetic overactivity (essential hypertension, hyperinsulinism, rheumatoid arthritis, and all TH-1 autoimmune diseases) [3, 24, 101-105]. At the gastrointestinal level, patients with reflux esophagitis [81, 82], duodenal ulcer [59, 60], ulcerative colitis [100, 106], and diarrheic periods (IBS) [88, 107, 108], as well as showing mucosal eosinophilia, always present adrenal sympathetic predominance and a TH-2 immunological profile, whereas patients affected by the spastic colon, biliary hypokinesia (no gallbladder emptying), Crohn's disease, etc., always have both underlying neural sympathetic predominance and TH-1 immunological profile [24, 25, 72, 94, 105, 109]. The above neuroautonomic and immunological information has allowed us to successfully treat hundreds of patients affected by such gastrointestinal disorders [108-115] (Table 1, Figs. 1, 2).

Hyperactivity of the adrenal sympathetic system underlies the diarrheic period of the IBS. At this stage, gastrointestinal and pancreatic sphincters remain open. The continued overflow of bilis is diverted to the duodenum; however, some fraction may reflux to the stomach and esophagus, whereas some other fraction of the biliary flow is discharged into the small bowel, at which level it enhances motility. The resultant hyper-peristalsis is enhanced by the inhibition of the release of serotonin from the myenteric plexa level [14]. These neurons send excitatory axons to the longitudinal muscular intestinal layer (which increases intestinal tone and interferes
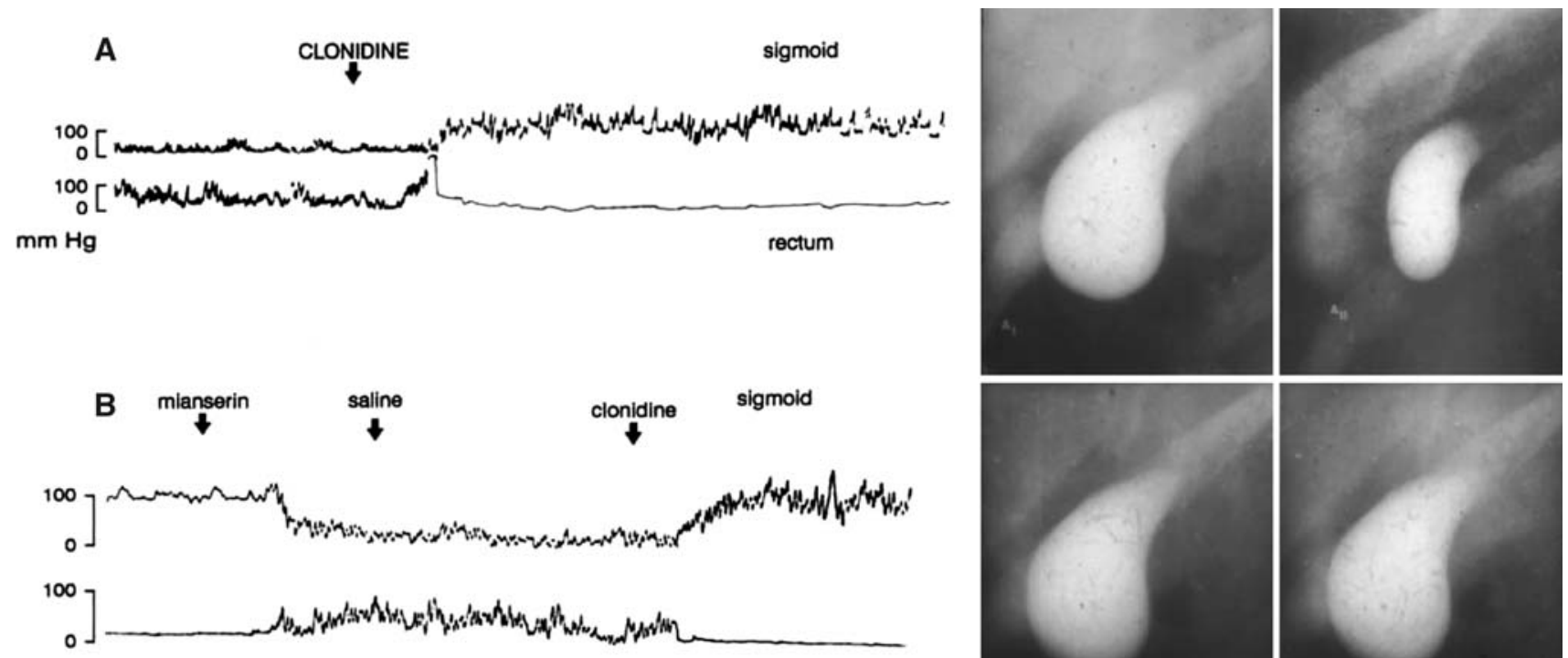

$\mathrm{mm} \mathrm{Hg}$

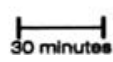

rectum
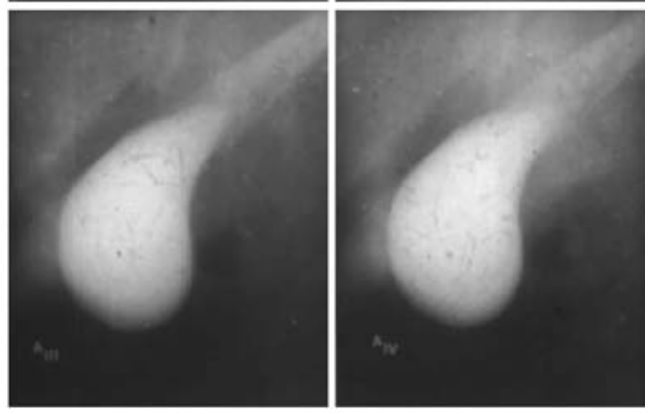

Fig. 1 Experimental evidence: physiological, pathophysiological, neuropharmacological, clinical, and therapeutic evidence dealing with the irritable bowel syndrome and biliary dyskinesia. Effects of the intramuscularly injected CCK $(0.5 \mathrm{U} / \mathrm{kg})$. CCK triggered the gallbladder to empty in a normal subject (upper). One week later, dihydroergotamine (DHE $1 \mathrm{mg}$ ) intramuscularly injected $45 \mathrm{~min}$ before CCK interfered with the gallbladder emptying (lower) and in addition provoked abdominal pain at the right-upper abdominal side.
At the plasma level, DHE provoked a significant rise of the plasma noradrenaline (NA) and an increase of the NA/Ad plasma ratio (neural sympathetic overactivity). Furthermore, significant reduction of the f5HT/p5HT ratio (hypo-parasympathetic activity) was registered after DHE administration. Finally, the above circulating neurotransmitters profile triggered by DHE administration was further reverted after clonidine administration 



Fig. 2 Effects of clonidine on the distal colon and biliary motility of a patient affected by spastic colon syndrome plus biliary dyskinesia. Clonidine ( $0.15 \mathrm{mg}$ intramuscularly injected) suppresses the diarrheic syndrome in a patient affected by irritable bowel syndrome (diarrheic period). Clonidine suppressed also the rectal hyperactivity and enhanced the sigmoidal tone (sigmoidal rectal junction). The X-ray study, carried out 3 days before this test, showed a normal gallbladder emptying after the Boyden (test) meal. However, the administration of oral clonidine $(0.15 \mathrm{mg}$ three times daily) reverted not only the distal colon motility profile, but also the diarrheic syndrome, and, in addition, triggered an increase of the sigmoidal tone plus the rectal hypomotility. No gallbladder emptying was registered during a second radiological study performed 8 days later during the clonidine trial (at which period the patient presented constipation and abdominal pain at both the right-upper hypochondrium and the left-lower abdominal zone). Further, a small dose of mianserine (an alpha-2 central-acting antagonist) intramuscularly injected reverted both the gallbladder and the colonic spasticity and in addition suppressed abdominal pains $[12,96]$

with peristalsis); thus, depletion of this serotonergic plexus reduces intestinal tone and facilitates peristalsis, which depends on the circular muscular layer. Considering that neural sympathetic and adrenal sympathetic activities are positively correlated with the above muscular layers, respectively, the disappearance of the spasticity (which depends on the external muscular layer) favors the activity of the circular (internal) muscular layer that enhances peristalsis. Summarizing the above, neural sympathetic activity is positively correlated with the myenteric (5HT) and longitudinal muscular layer responsible for the intestinal tone, whereas adrenal sympathetic activity favors intestinal hypotony and peristalsis [18, 116-120] (Figs. 3, 4).

At the CNS level, a great bulk of data allows associating neural sympathetic activity with the MR-5HT nucleus, whereas the adrenal sympathetic activity parallels the DR-5HT nucleus activity. Predominance of the former is associated with depression, whereas the latter CNS circuitry predominates during the uncoping stress syndrome $[25,39-41,43,44,88,103,104,121-124]$. These findings fit well with the psychiatric profiles registered during both types of IBS clinical periods. The above comments are supported by the routine assessment of circulating neurotransmitters in some 30,000 normal and diseased subjects, not only during supine-resting condition but also after many types of stressor agents and CNS-acting drugs [35, $37,44,46,123,125-127]$.

In summary, the assessment of circulating neurotransmitters carried out in our institute throughout the last 30 years showed that a lowered NA/Ad ratio $(<3)$ is registered during the diarrheic period, whereas the high NA/Ad ratio $(>7)$ is found during the spastic colon period [39-41, 43, $88,120,122,128,129]$.

Both the raised plasma serotonin (f5HT) and the reduced platelet serotonin (p5HT) levels registered during the diarrheic periods were reverted at the spastic colon period. The reversion of the above serotonin parameters should be associated with the reduction of platelet aggregation, which also paralleled the raised levels of circulating adrenaline, and in addition, to the fading of the adrenal sympathetic activity, which triggers platelet aggregation; thus, serotonin stored in the platelets is released to the plasma and further metabolized.

\section{Commentary Dealing with the Pathophysiology and Therapeutical Approaches of Pancreatic Inflammatory Diseases as Well as the Carcinoid Syndrome}

\section{Pancreatitis}

We have successfully treated 41 patients affected by acute pancreatitis; all patients have done well throughout the last 4 decades. All symptoms disappeared abruptly after the first intramuscular injection of clonidine $(0.15 \mathrm{mg})$; plasma amylase levels were normalized within the first $6 \mathrm{~h}$. Clonidine was administered every $6 \mathrm{~h}$ throughout the first $48 \mathrm{~h}$, and then it was progressively spaced. The dramatic improvement triggered by this alpha-2 (CNS-acting) agonist should be attributed to facts showing that the pancreatic innervation depends on the C1-Ad medullary nuclei, which also innervates salivary glands. The latter is consistent with findings showing that clonidine triggered 


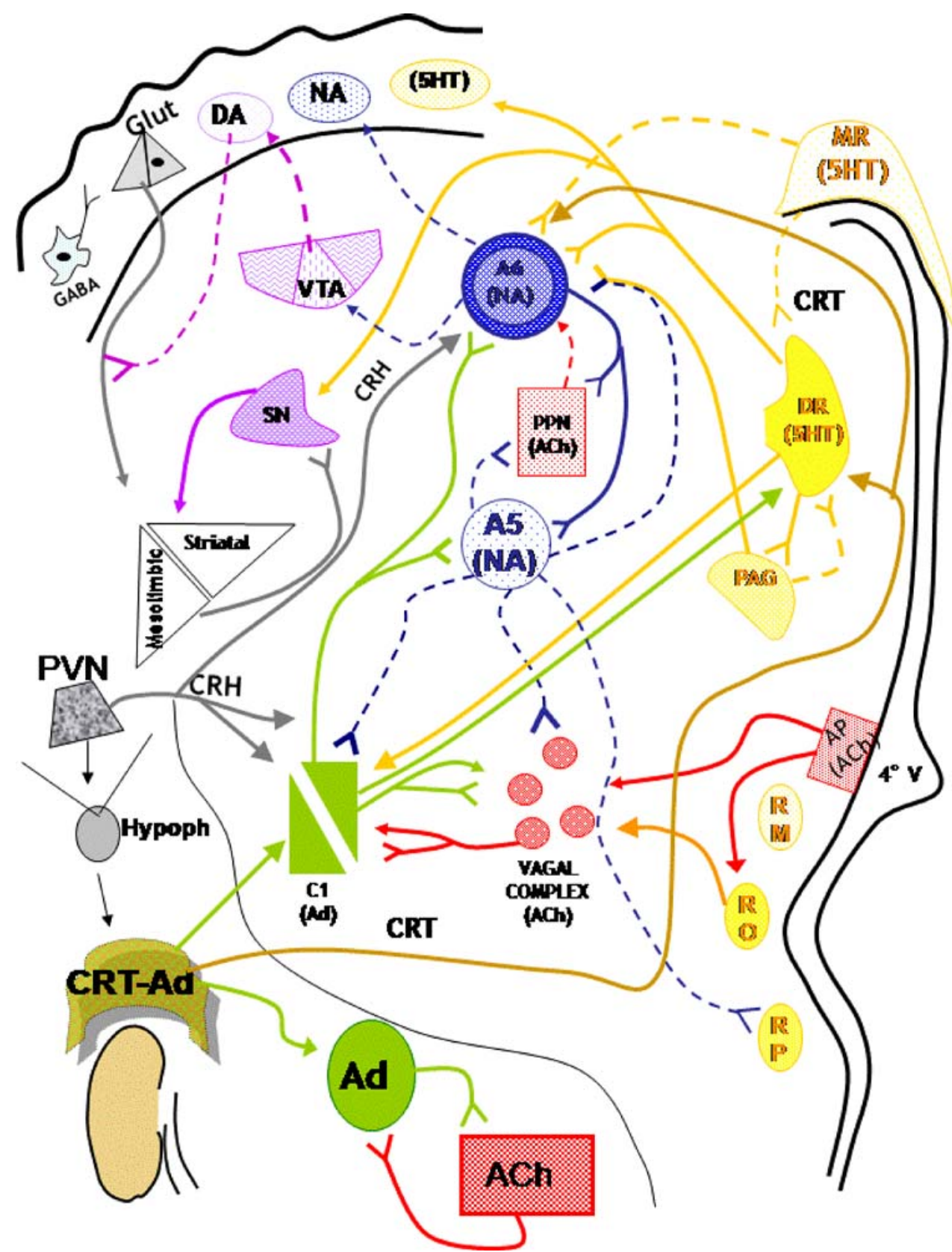

Fig. 3 Adrenal sympathetic activity. This peripheral branch of the autonomic nervous system (ANS) depends on the secretion of catecholamines by the adrenal gland $(80 \%$ of $\mathrm{Ad}+20 \%$ of NA + $10 \%$ DA). These glands receive excitatory axons from the thoracic presynaptic (ACh) neurons. These ACh neurons depend on the excitatory drives arising from the C1-Ad medullary nuclei, which in addition send inhibitory axons to both the A5(NA) and the A6(NA) nuclei. Furthermore, these subjects also present raised levels of plasma cortisol (CRT), which depends on the DR-5HT axons. This serotonergic nucleus interchanges excitatory drives with the $\mathrm{C} 1(\mathrm{Ad})$

dry mouth $[130,131]$. In addition, we demonstrated that clonidine relieves all types of pancreatic pain, which should be attributed to the reduction of the flow of pancreatic juice $[6-8,15-17,20-22,45,51,87,89,90,95-97$, 107, 109, 121, 131-147]. nuclei. Finally, both DR(5HT) and C1(Ad) axons excite the hypothalamic paraventricular nucleus. Furthermore, cortisol crosses the blood brain barrier and excites the DR-5HT. This positive feedback explains the raised levels of circulating Ad and CRT always registered in these patients. The above anatomical and physiological and pathophysiological mechanisms are reverted by administration of NA uptake inhibitors such as desipramine. Finally, the raised levels of Ad and CRT in the plasma are consistent with the bulk of clinical syndromes underlain by the uncoping stress syndrome

\section{Carcinoid Syndrome}

We have successfully treated nine patients affected by this disease (no failures). Our neuropharmacological therapeutic strategy is addressed to reduce the overwhelming 


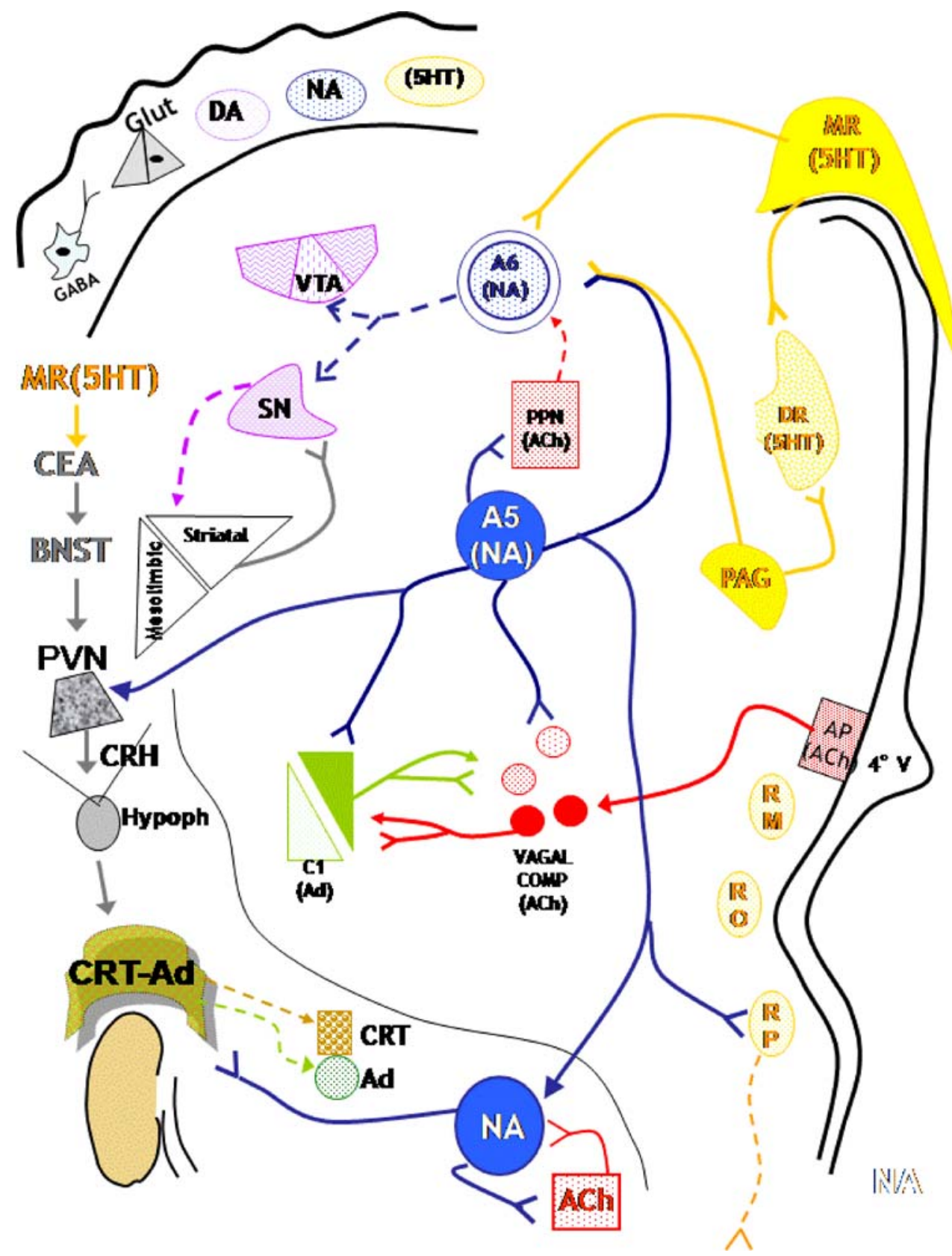

Fig. 4 Neural sympathetic activity. Neural sympathetic activity depends on the sympathetic nerves' release of NA $(90 \%)+$ DA $(10 \%)$. This branch of the peripheral autonomic nervous system (ANS) is positively correlated with activity of the ponto-medullary A5(NA) neurons, which excite the spinal sympathetic neurons and inhibit the $\mathrm{C} 1(\mathrm{Ad})$ medullary nuclei (responsible for the adrenal glands secretion). In addition, A5(NA) axons inhibit the medullary vagal complex. The absence of $\mathrm{C} 1$ (Ad) activity redounds in the hypoactivity of the DR(5HT) neurons. Serotonin released from these axons is the most important factor that initiates and prolongs the $\mathrm{CRH}$

parasympathetic activity that underlies this syndrome. This target was reached through the enhancement of the neural sympathetic activity that annuls both the adrenal and parasympathetic oscillations always registered in these secretion by the PVN hypothalamic nucleus. The minimization of this factor is consistent with the moderated rise of plasma CRT always registered during neural sympathetic overactivity. In addition, it has been demonstrated that sympathetic nerves inhibit adrenal gland secretion, directly by acting at alpha- 2 receptors located at these glands. This is consistent with the raised NA/Ad plasma ratio registered in these patients. Furthermore, overactivity of the sympathetic nerves provokes the vascular, bronchial, sphincteral (gastrointestinal, urinary) contraction always present at this circumstance

patients $[18,19,148]$. With respect to the above, it is well established that parasympathetic nerves excite enterochromaffin cells. Serotonin released by these cells to the portal vein is partially uptaked by the liver; however, some 
fraction escapes to this obstacle and reaches the lung at which level some other fraction of 5-HT is taken up by the pulmonary neuroendocrine cell (PNEC). The serotonin that escapes from lung and platelet uptake remains free in the plasma (f-5HT) and excites medullary area postrema (AP), which is located outside the blood brain barrier [116, 119]. The excitation of this nucleus, which is crowded by $5 \mathrm{HT}_{3}$ receptors [149], triggers the activation of the medullary vagal complex (nucleus tractus solitarii $=$ NTS), which is responsible for the hyper-secretion of serotonin by the enterochromaffin cells (Bezold-Jarisch reflex). The neuropharmacological manipulation addressed to enhance neural sympathetic activity (NA plasma level) provokes sustained clinical improvement plus the significant reduction of circulating serotonin [15, 17-19, 141, 150, 151].

Not only the carcinoid syndrome, but also cystic fibrosis, pancreatic and hepatic cysts have been successfully treated with the same neuropharmacological manipulation. These findings are consistent with the demonstration that the two latter diseases are underlain by raised levels of circulating serotonin as well as by lower NA plasma values. The above results indicate that adrenal sympathetic and parasympathetic over neural sympathetic predominance is responsible for the hyperactivity of the enterochromaffin cells that provokes the physiological disorders underlying carcinoid syndrome and cystic fibrosis of the pancreas [15-17, 131-133]. The above phenomena depend on the excitation of the C1-Ad nuclei by ACh-NTS axons [152, 153].

Open Access This article is distributed under the terms of the Creative Commons Attribution Noncommercial License which permits any noncommercial use, distribution, and reproduction in any medium, provided the original author(s) and source are credited.

\section{References}

1. Costa M, Furness JB, Llewellyn-Smith IJ (1987) Histochemistry of the enteric nervous system. In: Johnson LR, Christensen J, Jackson MJ, Jacobson ED, Walsh JH (eds) Physiology of the gastrointestinal tract, vol 1. Raven Press, New York, pp 1-40

2. Dockray GJ (1987) Physiology of enteric neuropeptides. In: Johnson LR, Christensen J, Jackson MJ, Jacobson ED, Walsh JH (eds) Physiology of the gastrointestinal tract, vol 1. Raven Press, New York, pp 41-67

3. Lechin F, van der Dijs B, Lechin E (1979) The autonomic nervous system. Physiological basis of psychosomatic therapy. Editorial Científico-Médica, Barcelona, España

4. Wetscher GJ, Hinder RA, Smyrk T, Perdikis G, Adrian TE, Profanter C (1999) Gastric acid blockade with omeprazole promotes gastric carcinogenesis induced by duodenogastric reflux. Dig Dis Sci 44:1132-1135. doi:10.1023/A:1026615905170

5. Lechin F, van der Dijs B (2007) Pathophysiology of biliary type abdominal pain. Dig Dis Sci 52:3157-3158. doi:10.1007/ s10620-006-9091-7

6. Lechin F, van der Dijs B, Orozco B (2002) Cholecystokinin (CCK) and secretin and pancreatic secretion of insulin and glucagon. Dig Dis Sci 47:2422-2423. doi:10.1023/A:1020 583203761

7. Lechin F, van der Dijs B (1979) Physiological effects of endogenous CCK on distal colon motility. Acta Gastroenterol Latinoam 9:195-201

8. Lechin F, van der Dijs B (1979) Colecistoquinina endógena y motilidad del colon distal. Acta Científica Ven 29(suppl 1):109-113

9. Moran TH (2000) Cholecystokinin and satiety: current perspectives. Nutrition 16:858-865. doi:10.1016/S0899-9007(00) 00419-6

10. Donovan MJ, Paulino G, Raybould HE (2007) CCK(1) receptor is essential for normal meal patterning in mice fed high fat diet. Physiol Behav 92:969-974. doi:10.1016/j.physbeh.2007.07.003

11. Elenkov IJ, Wilder RL, Chrousos GP, Vizi ES (2000) The sympathetic nerve-an integrative interface between two supersystems: the brain and the immune system. Pharmacol Rev 52:595-638 Review

12. Lechin F, van der Dijs B (1989) Neurochemistry and clinical disorders: circuitry of some psychiatric and psychosomatic syndromes. CRC Press, Boca Raton, FL

13. Weisbrodt NW (1987) Motility of the small intestine. In: Johnson LR, Christensen J, Jackson MJ, Jacobson ED, Walsh JH (eds) Physiology of the gastrointestinal tract. Raven Press, New York, pp 631-664

14. Gershon MD, Altman RF (1971) An analysis of the uptake of 5hydroxytryptamine by the myenteric plexus of the small intestine of the guinea pig. J Pharmacol Exp Ther 179:29-41

15. Lechin F, van der Dijs B (2005) Neuropharmacological therapy of carcinoid syndrome. Neuroendocrinology 81:137-138. doi: $10.1159 / 000086526$

16. Lechin F, van der Dijs B, Orozco B, Hernandez-Adrian G, Rodriguez S, Baez S (2005) Similar autonomic nervous system disorders underlying cystic fibrosis and pancreatic cysts allowed common neuropharmacological therapy: report of four cases. J Appl Res 5:299-304

17. Lechin F, van der Dijs B, Orozco B, Rodriguez S, Baez S (2005) Neuropharmacological therapy of the neuroendocrine carcinoid syndrome: report of two cases. J Appl Res 5:109-114

18. Tobe T, Izumikawa F, Sano M, Tanaka C (1976) Release mechanisms of 5-HT in mammalian gastrointestinal tractespecially vagal release of 5-HT. In: Fujita T (ed) Endocrine gut-pancreas. Elsevier, Amsterdam, pp 371-390

19. Tobe T (1974) Enterochromaffin cells and carcinoid syndrome. Nippon Rinsho 32:745-750

20. Lechin F, Coll-García E, van der Dijs B (1973) Efectos de la serotonina (5-HT) sobre la secreción de insulina por islotes aislados incubados in vitro. Acta Científica Ven 24(suppl 1):19-24

21. Lechin F, Coll-García E, van der Dijs B (1973) Efectos de la administración intraportal de serotonina (5-HT), sobre los niveles de glucosa e insulina inmuno-reactiva (IRI), de la vena pancreatoduodenal del perro. Acta Científica Ven 24(suppl 1):29-36

22. Lechin F, Coll-Garcia E, van der Dijs B, Peña F, Bentolila A, Rivas C (1975) The effect of serotonin (5-HT) on insulin secretion. Acta Physiol Latinoamer 25:339-346

23. Engeland WC (1998) Functional innervation of the adrenal cortex by the splanchnic nerve. Horm Metab Res 30:311-314 Review

24. Lechin F, van der Dijs B, Lechin ME (2002) Neurocircuitry and neuroautonomic disorders: reviews and therapeutic strategies. Karger, Basel

25. Lechin F, van der Dijs B (2008) Crosstalk between the autonomic nervous system and the central nervous system: mechanistic and therapeutic considerations for neuronal, immune, vascular, and somatic based diseases. In: Maiese K (ed) Neurovascular medicine: pursuing cellular longevity for healthy aging. Oxford University Press, New York 
26. Porta S, Emsenhuber W, Felsner P, Schauenstein K, Supanz S (1989) Norepinephrine triggers medullar epinephrine depletion during normoglycemia. Life Sci 45:1763-1769. doi:10.1016/ 0024-3205(89)90515-8

27. Li YW, Wesselingh SL, Blessing WW (1992) Projections from rabbit caudal medulla to $\mathrm{C} 1$ and $\mathrm{A} 5$ sympathetic premotor neurons, demonstrated with phaseolus leucoagglutinin and herpes simplex virus. J Comp Neurol 317:379-395. doi:10.1002/ cne. 903170405

28. Robertson D, Johnson GA, Robertson RM, Nies AS, Shand DG, Oates JA (1979) Comparative assessment of stimuli that release neuronal and adrenomedullary catecholamines in man. Circulation 59:637-643

29. Young JB, Rosa RM, Landsberg L (1984) Dissociation of sympathetic nervous system and adrenal medullary responses. Am J Physiol 247:E35-E40

30. Fenik V, Marchenko V, Janssen P, Davies RO, Kubin L (2002) A5 cells are silenced when REM sleep-like signs are elicited by pontine carbachol. J Appl Physiol 93:1448-1456

31. Byrum CE, Guyenet PG (1987) Afferent and efferent connections of the A5 noradrenergic cell group in the rat. J Comp Neurol 261:529-542. doi:10.1002/cne.902610406

32. Krowicki ZK, Hornby PJ (1993) Serotonin microinjected into the nucleus raphe obscurus increases intragastric pressure in the rat via a vagally mediated pathway. J Pharmacol Exp Ther 265:468-476

33. Langer SZ, Angel I (1991) Pre- and postsynaptic alpha-2 adrenoceptors as target for drug discovery. J Neural Transm Suppl 34:171-177

34. Lechin F, van der Dijs B, Pardey-Maldonado B, Benaim M, Baez S, Orozco B et al (2004) Circulating neurotransmitter profiles during the different wake-sleep stages in normal subjects. Psychoneuroendocrinology 29:669-685. doi:10.1016/ S0306-4530(03)00095-7

35. Lechin F, van der Dijs B, Jara H, Orozco B, Baez S, Benaim M et al (1998) Effects of buspirone on plasma neurotransmitters in healthy subjects. J Neural Transm 105:561-573. doi:10.1007/ s007020050079

36. Lechin F, van der Dijs B, Lechin ME, Orozco B, Báez S, Lechin AE et al (1997) Plasma neurotransmitters, blood pressure and heart rate during supine-resting, orthostasis, and moderate exercise conditions in two types of hypertensive patients. Res Comm Biol Psychol Psychiatry 22:111-145

37. Lechin F, van der Dijs B, Orozco B, Báez S, Rada I, León G et al (1996) Plasma neurotransmitters, blood pressure and heart rate during supine-resting, orthostasis and moderate exercise stress test in healthy humans before and after parasympathetic blockade with atropine. Res Comm Biol Psychol Psychiatry 21:55-72

38. Lechin F, van der Dijs B, Orozco B, Lechin AE, Báez S, Lechin ME et al (1996) Plasma neurotransmitters, blood pressure and heart during supine-resting, orthostasis and moderate exercise in severely ill patients: a model of failing to cope with stress. Psychother Psychosom 65:129-136

39. Lechin F, van der Dijs B, Lechin M (1996) Plasma neurotransmitters and functional illness. Psychother Psychosom 65:293-318 Review

40. Lechin F, van der Dijs B, Orozco B, Lechin ME, Acosta E, Lechin AE et al (1995) Plasma neurotransmitters, blood pressure and heart rate during supine-resting, orthostasis and moderate exercise conditions in major depressed patients. Biol Psychiatry 38:166-173. doi:10.1016/0006-3223(94)00258-5

41. Lechin F, van der Dijs B, Orozco B, Lechin AE, Báez S, Lechin $\mathrm{ME}$ et al (1995) Plasma neurotransmitters, blood pressure and heart rate during supine-resting, orthostasis and moderate exercise in dysthymic depressed patients. Biol Psychiatry 37:884891. doi:10.1016/0006-3223(94)00220-W
42. Lechin AE, Varon J, van der Dijs B, Lechin F (1994) Plasma neurotransmitters, blood pressure and heart rate during rest and exercise. Am J Respir Crit Care Med 149:A482

43. Lechin F, van der Dijs B, Lechin AE, Orozco B, Lechin ME, Báez $S$ et al (1994) Plasma neurotransmitters and cortisol in chronic illness: role of stress. J Med 25:181-192

44. Lechin F, van der Dijs B, Lechin M, Jara H, Lechin A, LechinBáez S et al (1993) Plasma neurotransmitters throughout an oral glucose tolerance test in essential hypertension. Clin Exp Hypertens 15:209-240. doi:10.3109/10641969309041621

45. Lechin F, van der Dijs B, Lechin M, Lechin-Báez S, Jara H, Lechin A et al (1992) Effects of an oral glucose load on plasma neurotransmitters in humans: involvement of REM sleep? Neuropsychobiology 26:4-11. doi:10.1159/000118889

46. Lechin F, van der Dijs B, Hernandez G, Orozco B, Rodriguez S, Baez $S$ (2006) Acute effects of tianeptine on circulating neurotransmitters and cardiovascular parameters. Prog Neuropsychopharmacol Biol Psychiatry 30:214-222. doi:10.1016/j.pnpbp. 2005.10.013

47. Lechin F, van der Dijs B (2007) Acute effects of sibutramine administration on the autonomic nervous system in obese subjects. Clin Pharmacol Ther 81:326. doi:10.1038/sj.clpt.6100065

48. Lechin F, van der Dijs B, Vitelli G, Lechin-Baez S, Azócar J, Cabrera A et al (1990) Psychoneuroendocrinological and immunological parameters in cancer patients: involvement of stress and depression. Psychoneuroendocrinology 15:435-451. doi:10.1016/ 0306-4530(90)90067-J

49. Lechin F, van der Dijs B, Lechin AE (2005) Circulating serotonin, catecholamines and CNS circuitry related to some cardiorespiratory and vascular disorders. J Appl Res 5:605-621

50. Lechin F, van der Dijs B, Lechin AE. Serotonin bronchial hyperresponsiveness and eosinophil-associated gastrointestinal disease. Gastroenterology, accepted for publication.

51. Lechin F (2000) Central and plasma 5-HT, vagal tone and airways. Trends Pharmacol Sci 21:425. doi:10.1016/S01656147(00)01565-0

52. Lechin F, van der Dijs B, Orozco B, Lechin ME, Lechin AE (1996) Increased levels of free-serotonin in plasma of symptomatic asthmatic patients. Ann Allergy Asthma Immunol $77: 245-253$

53. Lechin F, van der Dijs B (1981) Intestinal pharmacomanometry and glucose tolerance: evidence for two antagonistic dopaminergic mechanisms in the human. Biol Psychiatry 16:969-986

54. Lechin F, van der Dijs B (1973) A study of some immunological and clinical characteristics of gastritis, gastric ulcer, and duodenal ulcer in the three racial groups of the venezuelan population. Am J Phys Anthropol 39:369-374. doi:10.1002/ ajpa.1330390305

55. Lechin F (1977) Autoinmunidad y patologia gastroduodenal. Editorial. Acta Gastroenter Latinoamer 7:39-40

56. Larsson PT, Hjemdahl P, Olsson G, Egberg N, Hornstra G (1989) Altered platelet function during mental stress and adrenaline infusion in humans: evidence for an increased aggregability in vivo as measured by filtragometry. Clin Sci 76:369-376

57. Koob GF (1999) Corticotropin-releasing factor, norepinephrine, and stress. Biol Psychiatry 46:1167-1180. doi:10.1016/S00063223(99)00164-X Review

58. Kopin IJ, Eisenhofer G, Goldstein D (1988) Sympathoadrenal medullary system and stress. In: Chrousos GP, Loriaux DL, Gold PW (eds) Mechanisms of physical and emotional stress. Plenum Press, New York, pp 11-23

59. Jara H, Lechin A, Rada I, Villa S, Cabrera A, Guerrero H et al (1988) Plama neurotransmitters profile in duodenal ulcer patients. III interamerican congress of clinical pharmacology and therapeutics and XII Latinoamerican congress of pharmacology. Arch Ven Farm Clin Terap 7(suppl 1):86 
60. Lechin F, van der Dijs B, Rada I, Jara H, Lechin A, Cabrera A et al (1990) Plasma neurotransmitters and cortisol in duodenal ulcer patients: role of stress. Dig Dis Sci 35:1313-1319. doi:10.1007/BF01536734

61. Shrivastava RK, Siegal H, Lawlor R, Shah BK, Dayican G (1985) Doxepin therapy for duodenal ulcer: a controlled trial in patients who failed to respond to cimetidine. Clin Ther 7:319-326

62. Wetscher GJ, Hinder RA, Kretchmar D, Stinson R, Perdikis G, Smyrk T et al (1996) Duodenogastric reflux causes growth stimulation of foregut mucosa potentiated by gastric acid blockade. Dig Dis Sci 41:2166-2173. doi:10.1007/ BF02071396

63. Taylor PR, Mason RC, Filipe MI, Vaja S, Hanley DC, Murphy GM et al (1991) Gastric carcinogenesis in the rat induced by duodenogastric reflux without carcinogens: morphology, mucin histochemistry, polyamine metabolism, and labelling index. Gut 32:1447-1454. doi:10.1136/gut.32.12.1447

64. Lechin F, van der Dijs B, Lechin AE (2004) The autonomic nervous system assessment throughout the wake-sleep cycle and stress. Psychosom Med 66:974-976. doi:10.1097/01.psy. 0000146793.90058.c3

65. Ritchie WP (1984) Alkaline reflux gastritis: a critical reappraisal. Gut 25:975-987. doi:10.1136/gut.25.9.975 Review

66. Kaur BS, Ouatu-Lascar R, Omary MB, Triadafilopoulos G (2000) Bile salts induce or blunt cell proliferation in Barrett's esophagus in an acid-dependent fashion. Am J Physiol Gastrointest Liver Physiol 278:G1000-G1009

67. Gowen GF (1985) Spontaneous enterogastric reflux gastritis and esophagitis. Ann Surg 201:170-175. doi:10.1097/00000658198502000-00006

68. García Rodríguez LA, Lagergren J, Lindblad M (2006) Gastric acid suppression and risk of oesophageal and gastric adenocarcinoma: a nested case control study in the UK. Gut 55:15381544. doi:10.1136/gut.2005.086579

69. Lechin F, van der Dijs B (2005) Blood pressure and autonomic system assessment throughout the sleep cycle in normal adults. Sleep 28:645-646

70. Lechin F, van der Dijs B (1984) Slow wave sleep (SWS), REM sleep (REMS) and depression. Res Commun Psychol Psychiatr Behav 9:227-262

71. Lechin F, van der Dijs B, Azocar J, Amat J, Vitelli-Florez G, Martinez C et al (1987) Stress, immunology and cancer: effect of psychoactive drugs. Arch Ven Farm Clin Terap 6:28-43

72. Lechin F, van der Dijs B, Lechin S, Vitelli G, Lechin ME, Cabrera A (1989) Neurochemical, hormonal and immunological views of stress: clinical and therapeutic implications in Crohn's disease and cancer. In: Velazco M (ed) Recent advances in pharmacology and therapeutics. International congress series, vol 839. Excerpta Medica, Amsterdam, pp 57-70

73. Lechin S, Vitelli G, Martinez C, Fernández M, Cabrera A, van der Dijs B et al (1988) Plasma neurotransmitters, lymphocite subpopulations and natural killer cell activity in terminal cancer patients. III interamerican congress of clinical pharmacology and therapeutics and XII latinoamerican congress of pharmacology. Arch Ven Farm Clin Terap 7(suppl 1):37

74. Vitelli G, Lechin S, Cabrera A, Fernandez M, Azócar J, van der Dijs B et al (1988) Plasma neurotransmitters, lymphocyte subpopulations and natural killer cell activity in long-term symptomless cancer patients. III Interamerican Congress of Clinical Pharmacology and Therapeutics and XII Latinoamerican Congress of Pharmacology. Arch Ven Farm Clin Terap 7(Sup 1):Abst 36

75. van der Dijs B, Lechin S, Vitelli G, Cabrera A, Fernández M, Martinez C et al (1988) Plasma neurotransmitters, lymphocyte subpopulations and natural killer cell activity in progressive cancer patients. III interamerican congress of clinical pharmacology and therapeutics and XII latinoamerican congress of pharmacology. Arch Ven Farm Clin Terap 7(suppl 1):35

76. van der Dijs B, Lechin S, Vitelli G, Cabrera A, Fernandez M, Martinez C et al (1988) Plasma neurotransmitters, lymphocyte subpopulations and natural killer cell activity in short term symptomless cancer patients. III interamerican congress of clinical pharmacology and therapeutics and XII latinoamerican congress of pharmacology. Arch Ven Farm Clin Terap 7(suppl 1):34

77. Lechin F, van der Dijs B, Azocar J, Vitelli G, Lechin S, Villa S et al (1988) Neurochemical and inmunological profiles of three clinical stages in 50 advanced cancer patients. III interamerican congress of clinical pharmacology and therapeutics and XII latinoamerican congress of pharmacology. Arch Ven Farm Clin Terap 7(suppl 1):39

78. Lechin F, van der Dijs B (2008) Epinephrine, norepinephrine and cancer. J Biol Chem, accepted for publication

79. Lechin F, van der Dijs B, Lechin AE (2004) Natural killer cells activity and neuroimmunological treatment of cancer. Clin Cancer Res 10:8120-8121. doi:10.1158/1078-0432.CCR-041508

80. Sastry KS, Karpova Y, Prokopovich S, Smith AJ, Essau B, Gersappe A et al (2007) Epinephrine protects cancer cells from apoptosis via activation of camp-dependent protein kinase and bad phosphorylation. J Biol Chem 282:14094-14100. doi:10.1074/jbc.M611370200

81. Lechin M, Villa S, Rada I, Jara H, Cabrera A, Jimenez V et al (1988) Plasma neurotransmitters profile in reflux esophagitis. III interamerican congress of clinical pharmacology and therapeutics and XII latinoamerican congress of pharmacology. Arch Ven Farm Clin Terap 7(suppl 1):85

82. Lechin F, van der Dijs B, Rada I, Jara H, Lechin M, Cabrera A et al (1989) Recurrent gastroesophageal symptoms and precordial pain in a gastrectomized man improved by amytriptyline. Physiologic, metabolic, endocrine, neurochemical and psychiatric findings. J Med 20:407-424

83. Maling TJ, Dollery CT, Hamilton CA (1979) Clonidine and sympathetic activity during sleep. Clin Sci (Lond) 57:509-514

84. van Diest R, Appels WP (1994) Sleep physiological characteristics of exhausted men. Psychosom Med 56:28-35

85. Peyron C, Luppi PH, Fort P, Rampon C, Jouvet M (1996) Lower brainstem catecholamine afferents to the rat dorsal raphe nucleus. J Comp Neurol 364(3):402-413. doi:10.1002/(SICI)10969861(19960115)364:3<402::AID-CNE2>3.0.CO;2-8

86. Lechin F, van der Dijs B (1981) Glucose tolerance, non-nutrient drink and gastrointestinal hormones. Gastroenterology 80:216

87. Lechin F (1992) Adrenergic-serotonergic influences on gallbladder motility and irritable bowel syndrome. Am J Physiol Gastrointest Liver Physiol 262:G375-G376

88. Lechin F, van der Dijs B, Lechin-Báez S, Lechin A, Orozco B, Lechin $M$ et al (1994) Two types of irritable bowel syndrome: differences in behavior, clinical signs, distal colon motility and hormonal, neurochemical, metabolic, physiological and pharmacological profiles. Arch Ven Farmac Terap 12:105-114

89. Lechin F, van der Dijs B, Orozco B (2002) Gallbladder muscle dysfunction and neuroautonomic disorders. Gastroenterology 123:1407-1408

90. Lechin F, van der Dijs B, Lechin ME (2002) Neuropharmacological factors, biliary motility and pancreatitis. JOP 3:152-154

91. Lechin F, van der Dijs B, Gómez F, Arocha L, Acosta E (1982) Effects of d-amphetamine, clonidine and clonazepam on distal colon motility in non-psychotic patients. Arch Ven Farm Clin Terap 1:157-163

92. Lechin F, van der Dijs B (1982) Two postulated alpha2-antagonists (mianserin and chlorprothixene) and one alpha2-agonist (clonidine) induced opposite effects on human distal colon motility. Arch Ven Farm Clin Terap 1:160-169 
93. Lechin F, van der Dijs B, Gómez F, Valls JM, Acosta E, Arocha L (1980) Pharmacomanometric studies of colonic motility as a guide to the chemotherapy of schizophrenia. J Clin Pharmacol 20:664-671

94. Lechin F, van der Dijs B, Gómez F, Arocha L, Acosta E (1982) Effects of d-amphetamine, clonidine and clonazepam on distal colon motility in non-psychotic patients. Res Commun Psychol Psychiatr Behav 7:385-410

95. Lechin F, van der Dijs B, Bentolila A, Peña F (1978) The adrenergic influences on the gallbladder emptying. Am J Gastroenterol 69:662-668

96. Lechin F, van der Dijs B (1982) Intestinal pharmacomanometry as a guide to psychopharmacological therapy. In: Velazco M (ed) Clinical pharmacology and therapeutics. International congress series no. 604, Amsterdam, Excerpta Medica, pp 166-173

97. Lechin F, Gómez F, van der Dijs B, Lechin E (1980) Distal colon motility in schizophrenic patients. J Clin Pharmacol 20:459-464

98. Lechin F, van der Dijs B, Acosta E, Gómez F, Lechin E, Arocha L (1983) Distal colon motility and clinical parameters in depression. J Affect Disord 5:19-26. doi:10.1016/01650327(83)90032-0

99. Lechin F, van der Dijs B (1983) Opposite effects on human distal colon motility of two postulated alpha2-antagonists (mianserin and chlorprothixene) and one alpha2-agonist (clonidine). J Clin Pharmacol 23:209-218

100. Lechin F, van der Dijs B, Insausti CL, Gómez F, Villa S, Lechin AE et al (1985) Treatment of ulcerative colitis with clonidine. J Clin Pharmacol 25:219-226

101. Lechin F, van der Dijs B, Jakubowicz D, Camero RE, Villa S, Arocha L et al (1985) Effects of clonidine on blood pressure, noradrenaline, cortisol, growth hormone, and prolactin plasma levels in high and low intestinal tone depressed patients. Neuroendocrinology 41:156-162. doi:10.1159/000124174

102. Lechin F, van der Dijs B, Jakubowicz D, Camero RE, Villa S, Lechin E et al (1985) Effects of clonidine on blood pressure, noradrenaline, cortisol, growth hormone and prolactin plasma levels in low and high intestinal tone subjects. Neuroendocrinology 40:253-261. doi:10.1159/000124082

103. Lechin F, van der Dijs B, Hernandez-Adrian G (2006) Dorsal Raphe (DR) vs. Median Raphe (MR) serotonergic antagonism. Anatomical, physiological, behavioral, neuroendocrinological, neuropharmacological and clinical evidences: relevance for neuropharmacological therapy. Prog Neuropsychopharmacol Biol Psychiatry, 30:565-85. doi:10.1016/j.pnpbp.2005.11.025

104. Lechin F, van der Dijs B (2006) Central nervous system circuitry and peripheral neural sympathetic activity responsible for essential hypertension. Curr Neurovasc Res 3:307-325. doi: $10.2174 / 156720206778792894$

105. Lechin F, van der Dijs B (2007) Irritable bowel syndrome, depression and TH-1 autoimmune diseases. Dig Dis Sci 52:103104. doi:10.1007/s10620-006-9505-6

106. Lechin F, van der Dijs B, Insausti CL, Gómez F (1982) Treatment of ulcerative colitis with thioproperazine. J Clin Gastroenterol 4:445-449. doi:10.1097/00004836-198210000-00010

107. Lechin F, van der Dijs B, Azócar J, Lechin A, Gómez F, Amat J et al (1988) Plasma neurotransmitters profile in irritable bowel syndrome (IBS) diarrheic patients. III interamerican congress of clinical pharmacology and therapeutics and XII latinoamerican congress of pharmacology. Arch Ven Farm Clin Terap 7(suppl 1):88

108. Lechin F, van der Dijs B, Bentolila A, Peña F (1977) Antidiarrheal effects of dihydroergotamine. J Clin Pharmacol 17:339-349

109. Lechin F, van der Dijs B, Azócar J, Lechin A, Gómez F, Amat J et al (1988) Definite ans sustained improvement with psychoactive drugs of three Crohn's disease patients. III interamerican congress of clinical pharmacology and therapeutics and XII latinoamerican congress of pharmacology. Arch Ven Farm Clin Terap 7(suppl 1):89

110. Wrona D (2006) Neural-immune interactions: an integrative view of the bidirectional relationship between the brain and immune systems. J Neuroimmunol 172:38-58. doi:10.1016/ j.jneuroim.2005.10.017

111. Sandborn WJ, Loftus EV Jr, Colombel JF, Fleming KA, Seibold F, Homburger HA et al (2001) Evaluation of serologic disease markers in a population-based cohort of patients with ulcerative colitis and Crohn's disease. Inflamm Bowel Dis 7:192-201. doi:10.1097/00054725-200108000-00003

112. Romagnani S (1996) Th1 and Th2 in human diseases. Clin Immunol Immunopathol 80:225-235. doi:10.1006/clin.1996. 0118 Review

113. Madden KS, Felten SY, Felten DL, Sundaresan PR, Livnat S (1989) Sympathetic neural modulation of the immune system. I. Depression of $\mathrm{T}$ cell immunity in vivo and vitro following chemical sympathectomy. Brain Behav Immun 3:72-89. doi:10.1016/0889-1591(89)90007-X

114. Liebregts T, Adam B, Bredack C, Roth A, Heinzel S, Lester S et al (2007) Immune activation in patients with irritable bowel syndrome. Gastroenterology 132:913-920. doi:10.1053/ j.gastro.2007.01.046

115. Ladep NG, Obindo TJ, Audu MD, Okeke EN, Malu AO (2006) Depression in patients with irritable bowel syndrome in Jos, Nigeria. World J Gastroenterol 12:7844-7877

116. Porges SW (1995) Cardiac vagal tone: a physiological index of stress. Neurosci Biobehav Rev 19:225-233. doi:10.1016/01497634(94)00066-A Review

117. Newberry NR, Watkins CJ, Reynolds DJ, Leslie RA, GrahameSmith DG (1992) Pharmacology of the 5-hydroxytryptamineinduced depolarization of the ferret vagus nerve in vitro. Eur $\mathbf{J}$ Pharmacol 221:157-160. doi:10.1016/0014-2999(92)90786-4

118. Chowdhury AR, Dinoso VP, Lorber SH (1976) Characterization of a hyperactive segment at the rectosigmoid junction. Gastroenterology 71:584-588

119. Christensen NJ (1980) Adrenergic mechanisms in selected diseases: arterial hypertension, duodenal ulcer, primary depressive illness, malignant tumors, and ketotic hypoglycemia. Metabolism 29:1190-1197. doi:10.1016/0026-0495(80)90029-3

120. Reynolds DJM, Leslie RA, Grahame-Smith DG, Harvey JM (1989) Localization of $5-\mathrm{HT}_{3}$ receptor binding sites in human dorsal vagal complex. Eur J Pharmacol 174:127-130. doi:10.1016/0014-2999(89)90884-4

121. Lechin F, van der Dijs B (2006) Central nervous system (CNS) circuitry involved in the hyperinsulinism syndrome. Neuroendocrinology 84:222-234. doi:10.1159/000098005

122. Lechin F, van der Dijs B, Benaim M (1996) Stress versus depression. Prog Neuropsychopharmacol Biol Psychiatry 20:899-950. doi:10.1016/0278-5846(96)00075-9 Review

123. Lechin F, van der Dijs B, Jakubowicz D, Camero RE, Lechin S, Villa $S$ et al (1987) Role of stress in the exacerbation of chronic illness. Effects of clonidine administration on blood pressure, nor-epinephrine, cortisol, growth hormone and prolactin plasma levels. Psychoneuroendocrinology 12:117-129. doi:10.1016/ 0306-4530(87)90042-4

124. Lechin F, van der Dijs B, Amat J, Lechin ME (1986) Central neuronal pathways involved in depressive syndrome. Experimental findings. Res Commun Psychol Psychiatr Behav 11:145-192

125. Lechin F, van der Dijs B, Hernandez G, Orozco B, Rodriguez S, Baez S (2006) Effects of sibutramine on circulating neurotransmitters in healthy subjects. Neurotoxicology 27:184-191. doi:10.1016/j.neuro.2005.09.004

126. Lechin F, van der Dijs B, Baez S, Hernandez-Adrian G, Orozco $\mathrm{B}$, Rodriguez S (2006) The effects of oral arginine on neuroautonomic parameters in healthy subjects. J Appl Res 6:201-213 
127. Lechin F, van der Dijs B, Lechin A, Lechin M, Coll-Garcia E, Jara $\mathrm{H}$ et al (1991) Doxepin therapy for postprandial symptomatic hypoglycemic patients neurochemical, hormonal and metabolic disturbances. Clin Sci 80:373-384

128. Lechin F, van der Dijs B, Bentolila A, Peña F (1977) The spastic colon syndrome. Therapeutic and pathophysiological considerations. J Clin Pharmacol 17:431-440

129. Lechin M, Jara H, Rada I, Villa S, Cabrera A, Jimenez V et al (1988) Plasma neurotransmitters profile in irritable bowel syndrome (IBS); spastic colon patients (SCP). III interamerican congress of clinical pharmacology and therapeutics and XII latinoamerican congress of pharmacology. Arch Ven Farm Clin Terap 7(suppl 1):87

130. Roze C, Chariot J, Appia F, Pascaud X, Vaille C (1981) Clonidine inhibition of pancreatic secretion in rats: a possible central site of action. Eur J Pharmacol 76:381-390. doi:10.1016/ 0014-2999(81)90109-6

131. Lechin F, van der Dijs B (2008) Arginine-induced pancreatitis: involvement of the autonomic nervous system? Am J Physiol, accepted for publication. GI and Liver Physiology

132. Lechin F, van der Dijs B, Hernandez-Adrian G (2008) Neuropharmacological therapy for cystic fibrosis. BMJ. http:// www.bmj.com/cgi/eletters/335/7632/1255

133. Lechin F, van der Dijs B, Hernandez-Adrian G (2008) Clonidine therapy for pancreatitis. Dig Dis Sci 53:1434-1435. doi:10.1007/s10620-008-0220-3.

134. Lechin F, van der Dijs B (2004) Platelet aggregation, platelet serotonin and pancreatitis. JOP 5:8001-8003

135. Lechin F, van der Dijs B, Lechin M, Jara H, Lechin A, Cabrera A et al (1992) Clonidine treatment of acute pancreatitis: report of five cases. Acta Gastroenterol Latinoam 22:119-124

136. Lechin F, van der Dijs B, Lechin M, Jara H, Lechin A, Cabrera A et al (1992) Dramatic improvement with clonidine of acute pancreatitis showing raised catecholamines and cortisol plasma levels: case report of five patients. J Med 23:339-351

137. Lechin F, van der Dijs B (1981) Glucose tolerance, non-nutrient drink and gastrointestinal hormones. Gastroenterology 0:216

138. Lechin F, Coll-Garcia E, van der Dijs B, Bentolila A, Peña F, Rivas C (1979) The effects of dopaminergic blocking agents on the glucose tolerance test in six humans and six dogs. Experientia 35:886-887. doi:10.1007/BF01955130
139. Lechin F, Coll-Garcia E, van der Dijs B, Bentolila A, Peña F, Rivas C (1979) Effects of captivity on glucose tolerance in dogs. Experientia 35:876-877. doi:10.1007/BF01955123

140. Lechin F, Benshimol A, van der Dijs B (1970) Histalog and secretin effects on serum electrolytes. Influence of pancreatectomy and gastrectomy. Acta Gastroenterol Latinoam 2:9-18

141. Lechin $F$ (1962) The effect of secretin on serum potassium. Acta Physiol Latinoamer 12:370-376

142. Lechin F, van der Dijs B (1964) Glucose disposal. Lancet ii:1122. doi:10.1016/S0140-6736(64)92641-8

143. Lechin F (1966) Intestinal hormones and plasma insulin. Lancet ii: $35-37$

144. Lechin F (1963) Secretina y potasio sérico. G E N 17:347-351

145. Lechin $F$ (1954) New method of investigation of exocrine secretion of the pancreas. Gac Med Caracas 61:89-110

146. Lechin F (1952-1953) Un nuevo procedimiento para la exploración funcional exocrina del páncreas. G E N 8:1-2

147. Lechin F (1951) Diagnóstico de las afecciones pancreáticas mediante el estudio de sus fermentos. G E N 5:3-8

148. Cunnick JE, Lysle DT, Kucinski BJ, Rabin BS (1990) Evidence that shock-induced immune suppression is mediated by adrenal hormones and peripheral beta-adrenergic receptors. Pharmacol Biochem Behav 36:645-651. doi:10.1016/0091-3057(90)90270-R

149. Funahashi M, Mitoh Y, Matsuo R (2004) Activation of presynaptic 5-HT3 receptors facilitates glutamatergic synaptic inputs to area postrema neurons in rat brain slices. Methods Find Exp Clin Pharmacol 26:615-622. doi:10.1358/mf.2004.26.8.863726

150. Loewy AD, Haxhiu MA (1993) CNS cell groups projecting to pancreatic parasympathetic preganglionic neurons. Brain Res 620:323-330. doi:10.1016/0006-8993(93)90174-L

151. Loewy AD, Franklin MF, Haxhiu MA (1994) CNS monoamine cell groups projecting to pancreatic vagal motor neurons: a transneuronal labeling study using pseudorabies virus. Brain Res 638:248-260. doi:10.1016/0006-8993(94)90657-2

152. Urbanski RW, Sapru HN (1988) Evidence for a sympathoexcitatory pathway from the nucleus tractus solitarii to the ventrolateral medullary pressor area. J Auton Nerv Syst 23:161174. doi:10.1016/0165-1838(88)90080-X

153. Lechin F, van der Dijs B, Lechin AE (2004) Neural sympathetic activity in essential hypertension. Hypertension 44:e3-e4. doi:10.1161/01.HYP.0000133817.30057.2b 